\title{
EXPERIENCIA DE CAPACITACIÓN CON PERSPECTIVA DE GÉNERO. RUTA HACIA LA CIUDADANÍA
}

\author{
TRAINING EXPERIENCE WITH GENDER PERSPECTIVE: A ROUTE TOWARDS CITIZENSHIP
}

Aurelia Flores-Hernández ${ }^{* 1}$, Luz M. Martell-Ruíz², Carmen L. Flores-Moreno ${ }^{1}$

\begin{abstract}
${ }^{1}$ Centro de Investigaciones Interdisciplinarias sobre el Desarrollo Regional (CIISDER). ${ }^{2}$ Facultad de Trabajo Social, Sociología y Psicología. Universidad Autónoma de Tlaxcala (UATx) (aure7011@yahoo.com,1m79mr@hotmail.com, carmenleticiafloresmoreno@gmail.com)
\end{abstract}

\section{RESUMEN}

En este trabajo, a través de la sistematización de la experiencia de capacitación realizada durante el año 2012, producto de un proyecto financiado por el Fondo para el Desarrollo de las Instancias Municipales de las Mujeres (FODEIMM) aplicado en el municipio de San Salvador Tzompantepec, Tlaxcala, se tiene el propósito de reflexionar sobre las posibilidades que brinda capacitar con perspectiva de género. El estudio retoma como referentes teóricos a la ciudadanía activa y diferenciada, privilegiando el uso de técnicas que comprometen la investigación-acción. Las personas asistentes a las capacitaciones, en su mayoría mujeres, expresaron malestar e insatisfacción frente a su situación de vida en el contexto de su familia y su comunidad, lo que ayudó al reconocimiento de necesidades y problemas vinculados con la violencia de género, la transgresión de los derechos humanos y la invisibilización de la participación de las mujeres en la promoción del desarrollo local. El proceso de capacitación les facilitó el auto-reconocimiento como personas con derechos que las potencia como ciudadanas. La experiencia indica que este tipo de formaciones prometen a las personas capacitadas, particularmente a las mujeres, la adquisición de herramientas y conocimientos útiles y convenientes para posicionarse como ciudadanas.

Palabras clave: investigación-acción, mujeres, sistematización, talleres.

\section{INTRODUCCIÓN}

L as ideas acerca de la democracia y la ciudadanía tienen su origen en la antigua Grecia. Ambas conceptualizaciones refieren a la participación en la toma de decisiones y en el ejercicio del

* Autor responsable * Author for correspondence.

Recibido: abril, 2014. Aprobado: julio, 2014.

Publicado como ARTÍCULO en ASyD 11: 271-293. 2014.

\section{Abstract}

In this study, the purpose was reflecting upon the possibilities that training with gender perspective can afford, through the systematization of the training experience carried out during 2012, product of a project financed by the Fondo para el Desarrollo de las Instancias Municipales de las Mujeres (FODEIMM) in the municipality of San Salvador Tzompantepec, Tlaxcala. The study takes up active and differentiated citizenship as theoretical references, privileging the use of techniques that implicate research-action. The people who attend the trainings, mostly women, expressed uneasiness and dissatisfaction facing their living situation within the context of their family and their community, which helped in the recognition of needs and problems linked to gender violence, transgression of human rights, and the invisibilization of women's participation in the promotion of local development. The training process helped them in their self-recognition as people with rights, which makes them stronger as citizens. The experience indicates that this type of training promises people who are trained, particularly women, the acquisition of tools and helpful and convenient knowledge to position them as citizens.

Key words: research-action, women, systematization, workshops.

\section{INTRODUCTION}

$\mathrm{I}$ deas about democracy and citizenship have their origin in ancient Greece. Both concepts refer to the participation in decision-making and the exercise of public power (Grondona, 2000; Perissé, 2010). At that time, citizenship referred to a position of privilege that allowed people to intervene in the public space and granted them rights and obligations, which is why it is characterized by being highly participative and exclusive (Saltor and Espindola, 2008). 
poder público (Grondona, 2000; Perissé, 2010). En dicha época la ciudadanía aludía a una posición de privilegio que permitía a las personas la intervención en el espacio público y las dotaba de derechos y obligaciones, por lo que se caracteriza por ser altamente participativa y exclusiva (Saltor y Espindola, 2008).

En el momento en que los grupos gobernantes, la mayoría hombres, descubren que atribuyendo el carácter de "ciudadano" a ciertos individuos es posible delimitar espacios de acción y, en consecuencia, también derechos: mujeres libres y esclavas, hombres esclavos, y niños y niñas fueron descartadas de esta prerrogativa.

La Declaración de los Derechos del Hombre y del Ciudadano $(1789)^{1}$ constituye la base del concepto de ciudadanía en el que las mujeres permanecen ausentes (Castells, 2005). Con la entrada del Estado moderno aparecen tres atribuciones: la ciudadanía legal, que representó igualdad ante la ley; la ciudadanía política, que significó participación en asuntos públicos, y la ciudadanía nacional, que otorgó facultades al Estado. Sin embargo, las mujeres continuaron replegadas al ámbito privado (Vélez, 2006).

A lo largo de los últimos siglos estos derechos se han transformado y evolucionado a la par del desarrollo de la sociedad. Al respecto, Marshall (1997) distingue los siguientes momentos: a) una ciudadanía civil ampliada durante el Siglo VIII, vinculada a la libertad y a los derechos de propiedad; b) una ciudadanía política propia del Siglo XIX, ligada al derecho al voto y al derecho a la organización social y política; c) una ciudadanía social, extendida durante la última mitad del Siglo XX, relacionada con los sistemas educativos y el Estado del bienestar.

\section{Ciudadanía, GÉNERo Y CAPACITACión}

Al final de la década de los setenta del siglo pasado, el panorama político, económico y social se recrudeció cuando diversos grupos minoritarios denunciaron la violación a sus derechos humanos, con base en el género, la raza, las creencias, la preferencia sexual y la situación laboral, entre otros. Con la emergencia de los movimientos de identidad de las décadas de los ochenta y noventa se fortaleció la noción de ciudadanía activa, la cual es definida por Vargas (2000:173) como: "asumir un compromiso
At the moment when the governing groups, mostly men, discover that by attributing the character of "citizen" to certain individuals it is possible to limit action spaces and, consequently, also rights: free and slave women, slave men, and children were dismissed from this prerogative.

The Declaration of the Rights of Man and of the Citizen (1789) ${ }^{1}$ constitutes the basis of the concept of citizenship where women remain absent (Castells, 2005). With the entry of the modern State, three attributions appear: legal citizenship, which represented equality before the law; political citizenship, which meant participation in public affairs; and national citizenship, which granted rights to the State. However, women continued to be left back in the private scope (Vélez, 2006).

Throughout recent centuries these rights have been transformed and evolved at the same time than society's development. In this regard, Marshall (1997) distinguishes the following moments: a) civil citizenship broadened during the $18^{\text {th }}$ Century, linked to freedom and rights of property; b) political citizenship typical of the $19^{\text {th }}$ Century was linked to the right to vote and the right to social and political organization; c) social citizenship, extended during the second half of the $20^{\text {th }}$ Century and was linked to the educational systems and the welfare State.

\section{Citizenship, gender AND TRAINING}

At the end of the 1970s, the political, economic and social panorama intensified when diverse minority groups denounced the violation of their human rights, based on gender, race, beliefs, sexual preferences and the labor situation, among others. With the emergence of the identity movements during the 1980s and 1990s, the notion of an active citizenship was strengthened, which is defined by Vargas (2000:173) as: "assuming an active commitment in the deliberation of issues that affect the political community".

Thus, the person as a holder of rights and duties would become the creator of new spaces for citizen participation. Masbernat (1999) mentions that, through this, rights become effective and responsibilities and civic commitments are practiced. In this sense, active citizenship recognizes women 
activo en la deliberación de los temas que afectan a la comunidad política".

De esta manera, la persona como titular de derechos y deberes se convierte en creadora de nuevos espacios de participación ciudadana. Masbernat (1999) menciona que a través de ésta se hacen efectivos los derechos y se practican las responsabilidades y los comportamientos cívicos. En ese sentido la ciudadanía activa reconoce a las mujeres el papel que les corresponde en la búsqueda de acciones que fortalezcan su intervención en la toma de decisiones y asegura que se obtengan los beneficios o derechos de la pertenencia a la comunidad, demandando a las autoridades el respeto de sus compromisos, deberes y obligaciones. La ciudadanía puede actuar como "herramienta de movilización política", que vincula los diferentes proyectos feministas en las esferas local y global (Yuval-Davis, 1997).

La participación no se limita al ejercicio de la función pública o del poder político; se trata del cumplimiento de estos derechos y de la libertad que permite, además de la agrupación, la integración y la organización, sin las cuales no puede hablarse de ciudadanía. Por ello es necesario reconstruir el paradigma de este concepto, reconociendo la presencia de una esfera pública diferenciada, donde intereses políticos específicos se articulen a la agenda pública general y sean reivindicados por la totalidad de los actores.

Desde esta posición el feminismo de la diferencia propone constituir los derechos universales a través del concepto de ciudadanía diferenciada, definición que develaría el carácter históricamente restringido y parcial de la ciudadanía para las mujeres (Silva, 2005), y estimularía la evolución de la ciudadanía y la transición de derechos civiles, políticos, sociales y culturales (Hernández, 2009). En este sentido se requiere establecer una red indisoluble entre la construcción de la ciudadanía en estos términos, especialmente porque las demandas de las mujeres no están contempladas.

La proposición de ciudadanía diferenciada tiene como eje el cuestionamiento de las desigualdades y de las relaciones de poder, luego de que la tradición de un sistema hetero-normativo patriarcal ha restringido para las mujeres el ejercicio pleno y efectivo de la ciudadanía. La construcción de la ciudadanía es una deuda pendiente en la sociedad y para las mujeres (Báez y Paiewonsky, 2002), además de que ésta continuará siendo casi imposible en tanto la división in the role that corresponds to them in the search for actions that strengthen their intervention in decision-making and guarantees that the benefits or rights of belonging to a community are obtained, demanding from authorities the respect of their commitments, duties and obligations. Citizens can act as a "tool for political mobilization" that connects the different feminist projects in the local and global spheres (Yuval-Davis, 1997).

Participation is not limited to the exercise of public function or political power; it is about the fulfillment of these rights and the freedom they allow, in addition to grouping, integration and organization, without which there can be no talk of citizenship. Therefore, it is necessary to rebuild the paradigm of this concept, recognizing the presence of a differentiated public sphere, where specific political interests are articulated into the general public agenda and claimed by the totality of actors.

From this position, feminism of difference proposes constructing the universal rights through the concept of differentiated citizenship, a definition that would reveal the historically restricted and partial character of citizenship for women (Silva, 2005), and would stimulate the evolution of citizenship and the transition of civil, political, social and cultural rights (Hernández, 2009). In this sense, an indissoluble network must be established among the construction of citizenship in these terms, especially because the demands of women are not contemplated.

The proposition of a differentiated citizenship has as the axis the questioning of inequalities and power relations, after the tradition of a patriarchal heteronormative system has restricted the full and effective exercise of citizenship for women. The construction of citizenship is a pending debt in society, and for women (Báez and Paiewonsky, 2002), in addition to continuing to be almost impossible, insofar as the sexual division of labor is maintained and men refuse to accept their participation in domestic tasks (Okin, 1994; cited in Vargas, 2000).

The vote, property and liberty to organize themselves, among others, are the rights that women have gained access to rather later than men, as there are currently social groups where they are relegated to a second-rate citizenship or they occupy a "borrowed citizenship" that occurs only when men, for various reasons (migration, state of health), are prevented from exercising theirs. This nominal citizenship 
sexual del trabajo se mantenga y los hombres se nieguen a aceptar su participación en las tareas domésticas (Okin, 1994; citada en Vargas, 2000).

El voto, la propiedad, la libertad para organizarse, entre otros, son derechos a los que las mujeres han accedido más tardíamente que los hombres, encontrando en la actualidad grupos sociales donde ellas son relegadas a una ciudadanía de segunda u ostentan una "ciudadanía prestada" que ocurre sólo cuando los hombres, por diversas razones (migración, estado de salud), están imposibilitados para ejercerla. Esta ciudadanía nominal o de imagen pública genera en las mujeres toma de conciencia de sus derechos y reconocimiento comunitario de su participación, además de que visibiliza los múltiples papeles que emprenden, lo que les permite avanzar paulatinamente hacia procesos de empoderamiento (Martínez, 2014).

Pero, ¿cómo poder construir una ciudadanía fortalecida? En términos de los planteamientos de Marshall (1997) es a partir de la educación. Un individuo, hombre o mujer, que no esté formado no contará con herramientas para elegir libremente. $\mathrm{Al}$ igual que Jiménez (2005), creemos que educar para la ciudadanía es una obligación social urgente y necesaria para que una persona acceda al ejercicio de sus derechos, tenga la posibilidad de alcanzar un mayor estatus $y$, en consecuencia, reduzca la desigualdad.

Para las mujeres el acceso a la educación formal y no formal fortalece su capacidad de agencia; con ello están más informadas y cuentan con herramientas que estimulan una participación crítica. Esto significa el primer paso para el ejercicio pleno de la ciudadanía. La promoción de la ciudadanía con perspectiva de género implica el reconocimiento de que una sola "voz" y un accionar individual es insuficiente; es necesario tener espacios para hablar de los derechos que corresponden a las ciudadanas y los ciudadanos, decisiones tomadas en colectivo, organización en grupos, acceso de las mujeres a cargos públicos, promoción de liderazgo (Bulbeck, 1998) y capacitación.

Desde la perspectiva de género se aboga por una formación que considere la multiplicidad de funciones que las mujeres cumplen en la reproducción y cómo esto les posibilita o no vincularse como agentes individuales y sociales en condiciones de igualdad (Medrano, 1991; citado en Silva, 2005). Yuval-Davis (1997) aborda la relación que se establece entre la familia (lo privado) y lo político (lo público) para excluir del ejercicio de la ciudadanía a ciertos grupos, for public image generates in women awareness of their rights and community recognition of their participation, in addition to making the multiple roles that they undertake visible, which allows them to gradually advance towards empowering processes (Martínez, 2014).

However, how can a strengthened citizenship be built? In terms of the suggestions by Marshall (1997), it is through education. An individual, man or woman, who is not educated, will not have the tools to choose freely. Like Jiménez (2005), we believe that educating for citizenship is an urgent social obligation and something necessary for a person to gain access to their rights and to have the possibility of reaching a higher status and, consequently, to reduce inequality.

For women, access to formal and informal education strengthens their agency capacity; with it, they are more informed and have the tools to stimulate critical participation. This entails the first step towards a full exercise of citizenship. The promotion of citizenship with gender perspective implies the recognition that a single "voice" and individual acts are insufficient; it is necessary to have spaces to speak of the rights that correspond to men and women citizens, for decisions made collectively, organization into groups, access of women to public positions, promotion of leadership (Bulbeck, 1998), and training.

From the gender perspective, training that takes into account the multiplicity of functions that women fulfill in reproduction and how this allows them, or not, to connect as individual and social agents under conditions of equality is advocated (Medrano, 1991; cited in Silva, 2005). Wuval-Davis (1997) approaches the relationship that is established between the family (private) and the political (public) to exclude certain groups from the exercise of citizenship, particularly women. In addition, she advocates for a broader interpretation about citizenship that is not centered exclusively on the relationship between the person and the State.

Legal and/or institutional solutions must be combined with education and activities for skill building, in addition to the shaping of spaces for dialogue and incidence (Sever, 2004). Citizenship with this perspective supports a policy of inclusion that considers training and sensibilization with a gender approach, and the performance of affirmative 
en particular a las mujeres. Además, aboga por una interpretación más amplia sobre ciudadanía que no se centre exclusivamente en la relación entre las personas y el Estado.

Las soluciones legales y/o institucionales deben estar combinadas con educación y actividades de construcción de habilidades, además de formación de espacios para el diálogo y la incidencia (Sever, 2004). La ciudadanía con esta mirada apoya una política de inclusión que considere la capacitación y la sensibilización con enfoque de género, y la realización de acciones afirmativas (INMUJERES, 2009). Martínez y Díaz (2005) documentan que para el caso mexicano las capacitaciones han estado impregnadas de proposiciones para solucionar necesidades prácticas de las mujeres, concretamente en la ideología que mantienen las relaciones de desigualdad entre los géneros, aunque en las últimas décadas destacan aquellos procesos de habilitación que estimulan el empoderamiento de las mujeres.

La capacitación puede delinear la ruta hacia la ciudadanía, constituyéndose simultáneamente en herramienta y espacio donde ésta se comienza a gestar. Además de orientarse hacia la reflexión ideológica y de intereses estratégicos (situación, toma de conciencia, búsqueda de soluciones a problemáticas específicas en los espacios públicos y privados, entre otros) (Celarié et al., 2008), no solo estimula a alcanzar la ciudadanía, sino que plantea también cómo ésta puede ser utilizada para explicar y fortalecer aquellos elementos en las vidas de las personas que constituyen su pertenencia a una comunidad (Yuval -Davis, 1997).

Para continuar con estas reflexiones, en este trabajo nos interesamos en describir la importancia de la capacitación con perspectiva de género. Para dar cuenta de en qué medida la adquisición de herramientas formativas con esta orientación contribuye a que las mujeres en particular asuman su ciudadanía, se recupera la experiencia de capacitación derivada de un proyecto financiado a través del Fondo para el Desarrollo de las Instancias Municipales de las $\mathrm{Mu}$ jeres (FODEIMM) en el municipio de San Salvador Tzompantepec, Tlaxcala, ejecutado durante $2012^{2}$.

\section{Metodología Aplicada}

Fals Borda (2008) enuncia de manera precisa el gran desafío que representa en la época actual la adopción de metodologías que busquen no solo la explicación actions (INMUJERES, 2009). Martínez and Díaz (2005) documented that for the Mexican case, the trainings have been imbued with propositions to solve practical needs of women, concretely with the ideology that maintains relationships of inequality between the genders, although in recent decades, processes of habilitation that stimulate women's empowerment stand out.

Training can outline the route towards citizenship, constituting simultaneously a tool and space where it begins to develop. In addition to being directed towards ideological reflection and strategic interests (situation, awareness, search for solutions to specific problems in public and private spaces, among others) (Celarié et al., 2008), training not only stimulates citizenship but also suggests how it can be used to explain and strengthen those elements in the lives of people constituting their belonging to a community (Yuval-Davis, 1997).

To continue with these reflections, in this study we are interested in describing the importance of training with gender perspective. To account for the degree to which the acquisition of formative tools with this orientation contributes to women assuming their citizenship, in particular, the experience in training derived from a project financed through the Fund for the Development of Women's Municipal Instances (Fondo para el Desarrollo de las Instancias Municipales de las Mujeres, FODEIMM) in the municipality of San Salvador Tzompantepec, Tlaxcala, executed during $2012^{2}$.

\section{METHODOLOGY APPLIED}

Fals Borda (2008) describes with precision the great challenge represented by the adoption of methodologies that seek not only the explanation of events, but also the comprehension of their complexities and environs. In particular, the research-action as methodological orientation stands out, which facilitates "the search for knowledge in a collective manner [...], the systematic return and ease in understanding for people of common knowledge thus acquired [...] the sum of knowledge between formal academic knowledge and informal wisdom or popular experience" (Fals Borda, 2008:85), where personal experience and the moral and ideological commitment of the person performing the research is fundamental. 
de los acontecimientos, sino la comprensión de sus complejidades y sus contornos. En particular destaca la investigación-acción como orientación metodológica, que facilita "la búsqueda del conocimiento en forma colectiva [...] la devolución sistemática y fácil de entender para la gente del común del conocimiento así adquirido [...] la suma de saberes entre el conocimiento académico formal y la sabiduría informal o experiencia popular" (Fals Borda, 2008:85) donde la vivencia personal y el compromiso moral e ideológico de quien investiga es fundamental.

Proposiciones bastante similares emergen en la estrategia metodológica de investigación-reflexiónacción la cual, al ser situada en la práctica social, permite a la población tomar conciencia de su cotidianidad, sus prácticas, necesidades y problemas, gestando alternativas para construir mejores condiciones de vida (Flores y Gómez, 1999).

Además de estos puntos que comparten ambas proposiciones, la articulación también ubica la relación sujeto-sujeto y, en consecuencia, el reconocimiento de la otra persona como agente activa y, a su vez, la aceptación de que quien investiga también aprende. La generación de este espacio para la capacitación es recreado por los agentes participantes en el proceso y admite acciones que transforman el entorno y revitalizan nuevas formas de aprehender e interpretar la realidad.

Para la sistematización y recuperación de la información se introdujo como técnica central la capacitación a través de talleres, por considerar que éstos podían funcionar como espacios idóneos para la reflexión colectiva, el aprendizaje, la creatividad y la construcción de propuestas y alternativas, además de posibilitar el intercambio de información, de experiencias y de conocimiento, y estrategias para que la toma de decisiones ocurra en condiciones de igualdad entre hombres y mujeres (Avilés et al., 2005; Jiménez, 2005).

En este proceso de capacitación, el género se constituyó en una categoría fundamental para la reflexión. Celarié et al. (2008:46) mencionan que "cuando estos procesos [de capacitación] se impulsan desde la perspectiva de género buscan proporcionar a las mujeres herramientas básicas que les permitan revalorar su papel en la sociedad, generar y operar sus propios programas basados no en necesidades impuestas sino en aquellas que parten de intereses propios a partir de su propia vida cotidiana”.

Al recurrir a la mirada de género se apoyó la comprensión de las vivencias, intentando contribuir
Rather similar propositions emerge in the methodological strategy of research-refection-action, which, when situated into social practice, allows the population to become aware of its daily life, practices, needs and problems, managing alternatives to establish better living conditions (Flores and Gómez, 1999).

In addition to those points that both proposals share, the articulation also locates the subject-subject relationship and, as consequence, the recognition of the other person as an active agent and, in its turn, the acceptance that whomever is researching also learns. The generation of this space for training is recreated by the participant agents in the process and admits actions that transform the environment and revitalize new ways of apprehending and interpreting reality.

For the systematization and recuperation of information, training through workshops was introduced as the central technique, because it is considered that these could function as ideal spaces for collective reflection, learning, creativity and the construction of proposals and alternatives, in addition to making the exchange of information, experiences and knowledge possible, as well as the strategies for decision-making to occur under conditions of equality between men and women (Avilés et al., 2005; Jiménez, 2005).

During this training process, gender is constituted into a fundamental category for reflection. Celarié et al. (2008:46) mention that "when these [training] processes are driven from a gender perspective, they seek to provide women with the basic tools to allow them to revalue their role in society, generate and operate their own programs based not on imposed needs but rather on those that stem from their own interests, from their own daily life".

When resorting to the gender point of view, understanding of the experiences was supported, attempting to contribute to processes of gaining awareness and, particularly, to the construction of viable solutions "from, for and with" the trainee groups. In addition, we began from the recognition that "those who were training" and "those who were trained" live under rather similar "gender marks" (Morgade, 2011), although taking into account that among one and the other the experiences are different, but at the same time determined by practices of gender discrimination, both in "our" and 
a procesos de concientización y, particularmente, de construcción de soluciones viables "desde, para y con” los grupos capacitados. Además, partimos del reconocimiento de "quienes capacitábamos" y a "quienes capacitamos" vivimos bajo "marcas de género" (Morgade, 2011) bastante parecidas, aunque tomando en cuenta que entre unas y otras las vivencias son distintas, pero al mismo tiempo están determinadas por prácticas de discriminación de género, tanto en "nuestros" contextos como en los "suyos", a pesar de que como grupo humano contamos con un conjunto de derechos, obligaciones y libertades.

\section{El lugar de la experiencia: San Salvador Tzompantepec, Tlaxcala}

La comunidad de Tzompantepec se funda con la llegada de Hernán Cortés, quien al utilizarla como refugio instaló un altar en un árbol llamado tzompantle, ubicado en el cerro del Chichimecatleutli, a partir de ese momento el lugar fue bautizado con el nombre de San Salvador. Ahí fue librada la batalla de Tzompancingo, la primera que el ejército español enfrentó con el pueblo originario, y donde los habitantes se dieron cuenta que los caballos no eran mitad humanos, mitad animales, como se creía, y se les reconoció como bestias. En 1823, Encarnación Matamoros y Bartolomé Montiel fundan el municipio. Entre 1908 y 1914 del siglo pasado hubo una epidemia de viruela que dejó muchas muertes. Para 1920 se erige la escuela primaria Narciso Mendoza.

En la década de los treinta del siglo XX se realizaba un gran mercado regional al que la gente acudía a vender e intercambiar diversos alimentos, semillas y ganado. Su auge declinó y los pobladores buscaron otras estrategias de ingresos. La actividad artesanal se presentó como una opción para la comercialización de objetos de barro bruńido y rojo cocido, ollas grandes esgrafiadas y pintadas, y los típicos comales que aún persisten.

Durante de las décadas de los cincuenta y sesenta se inauguró la telesecundaria y se abrieron los primeros caminos de mayor extensión para una comunicación más rápida. Hacia la mitad de los años sesenta ocurrió un acelerado flujo migratorio a la Ciudad de México, coincidente con otros tránsitos suscitados por todo el Estado, a causa de que la extensión de tierra para cultivar era cada vez menor y el proceso de industrialización se aceleraba (Flores, 2010). "their" contexts, in spite of the fact that as a human group we have a portfolio of rights, obligations and freedoms.

\section{The place of the experience: San Salvador Tzompantepec, Tlaxcala}

The community of Tzompantepec was founded with the arrival of Hernán Cortés, who used it as a refuge and installed an altar on a tree called tzompantle, located on the hill of Chichimecatleutli; from that time the place was baptized with the name of Saint Savior (San Salvador). The battle of Tzompancingo was held there, the first where the Spanish army faced a native people, and where inhabitants realized that the horses were not half human, half animal, as was believed, and recognized as beasts. In 1823, Encarnación Matamoros and Bartolomé Montiel founded the municipality. Between 1908 and 1914 there was a smallpox epidemic that left many deaths. By 1920, the first primary school, Narciso Mendoza, was founded.

During the 1930s, a large regional market was held where people went to sell and exchange various foods, seeds and livestock. Its height declined and its inhabitants sought other strategies for income. Artisanal activity was presented as an option for commercialization of polished and terracotta red clay objects, large sgraffito and painted pots, and the typical griddles that still persist.

During the 1950s and 1960s the tele-secondary school was inaugurated and the first roads of greater extension were opened, for a faster communication. Towards the mid-1960s an accelerated migratory flow to Mexico City occurred, which coincided with other transits that arose throughout the State, because the land extension for cultivation was increasingly less and the industrialization process was accelerating (Flores, 2010).

Currently the municipality has 14611 inhabitants; 7528 women $(51.52 \%)$ and 7083 men (48.48\%). The central economic activities of the population are agriculture, livestock production and pottery; an important number of inhabitants travel to nearby cities to work in factories and other activities in the tertiary sector (INEGI, 2010).

The municipality covers a surface of $23240 \mathrm{~km}^{2}$, which represents $0.57 \%$ of the total state territory. It is located east of the state at the skirts of the 
En la actualidad el municipio cuenta con 14611 habitantes; 7528 mujeres (51.52\%) y 7083 hombres (48.48\%). Las actividades económicas centrales de la población son agricultura, ganadería y alfarería; un importante número de habitantes se traslada a ciudades cercanas para trabajar en fábricas y otras actividades del sector terciario (INEGI, 2010).

El municipio comprende una superficie de 23240 $\mathrm{km}^{2}$, lo que representa $0.57 \%$ del total del territorio estatal. Está ubicado al oriente del Estado y en las faldas del Volcán la Malinche; colinda con los municipios de Coaxomulco, Xaloztoc, San José Teacalco, Tocatlán, Santa Cruz Tlaxcala y dos de las principales ciudades del Estado: Apizaco y Huamantla (Figura 1). Sus principales localidades son San Andrés Ahuashuatepec, San Salvador Tzompantepec, San Juan Quetzalcoapan, Xaltianquisco y San Mateo Inophil (INEGI, 2010).

\section{Resultados y Discusión}

\section{Las personas participantes en la capacitación}

La invitación a participar en las capacitaciones fue dirigida a población abierta; se intentó involucrar a
Malinche volcano; it borders with the municipalities of Coaxomulco, Xaloztoc, San José Teacalco, Tocatlán, Santa Cruz Tlaxcala and two of the main cities in the state: Apizaco and Huamantla (Figure 1). The main localities are San Andrés Ahuashuatepec, San Salvador Tzompantepec, San Juan Quetzalcoapan, Xaltianquisco and San Mateo Inophil (INEGI, 2010).

\section{Results AND Discussion}

\section{The people who participate in the training}

The invitation to participate in the trainings was directed at the open population; there was an attempt to involve men, but the truth is that this type of activities is considered a "woman's issue", which is why the impact among them was minimal. In four out of the five workshops the number of men was small (Table 1).

On Table 2 we classified the responses with regard to the main activities that they are devoted to, which they reported, highlighting unpaid domestic labor for women, although around $16 \%$ mentioned some type of income-generating activity.

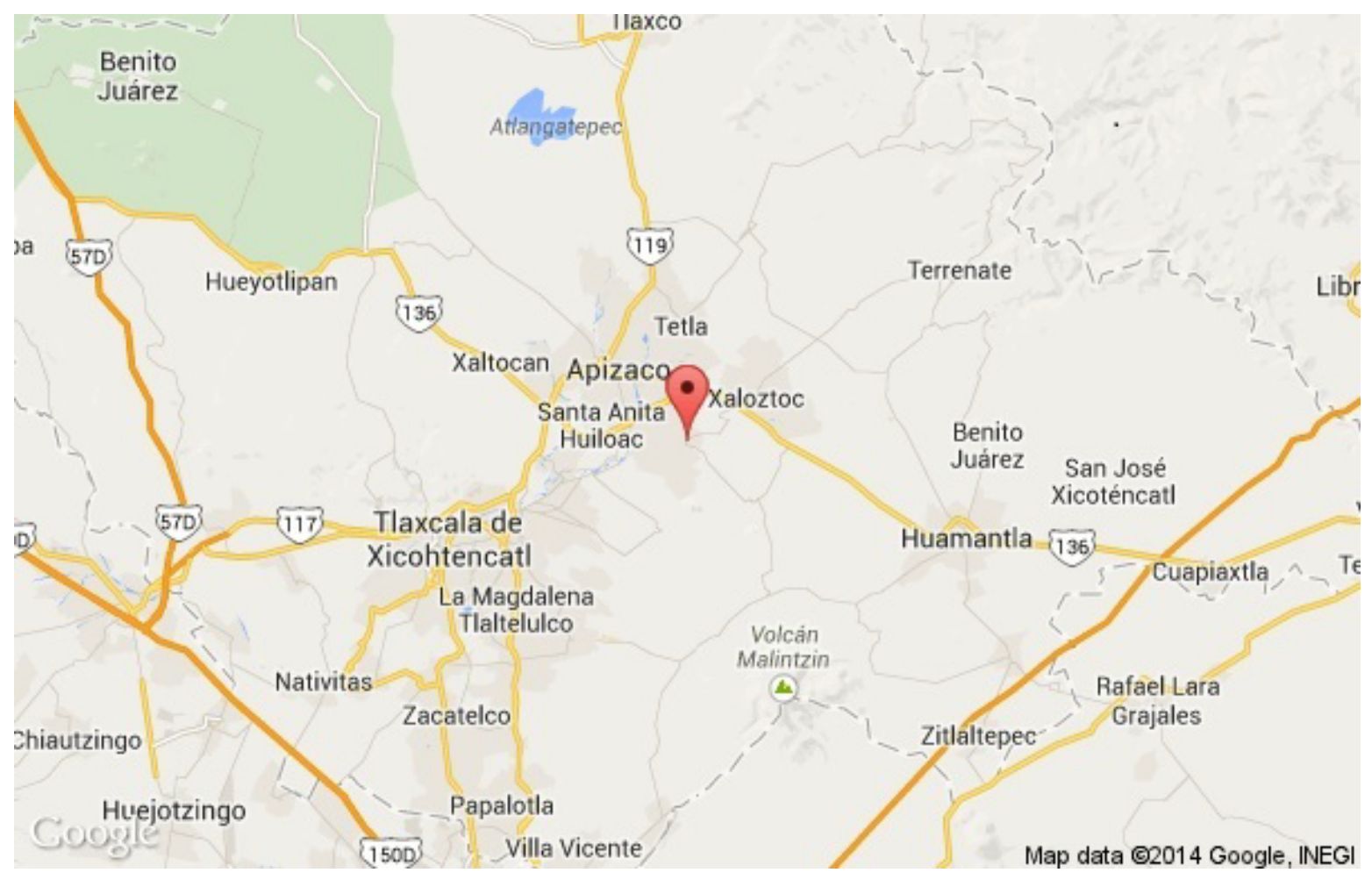

Figura 1. Localización de Tzompantepec, Tlaxcala.

Figure 1. Location of Tzompantepec, Tlaxcala. 
Cuadro 1. Participantes por localidad y sexo. Table 1. Participants per locality and sex.

\begin{tabular}{lccc}
\hline Localidad & Hombres & Mujeres & Total \\
\hline San Salvador Tzompantepec & 1 & 6 & 7 \\
San Andres Ahuashuatepec & 0 & 15 & 15 \\
San Juan Quetzalcoapan & 2 & 14 & 16 \\
Xaltianquisco & 0 & 18 & 18 \\
San Mateo Inophil & 1 & 23 & 24 \\
\hline Total & 4 & 76 & 80 \\
\hline
\end{tabular}

Fuente: elaboración propia con base en trabajo de campo (2012). - Source: authors' elaboration based on field work (2012).

varones, pero la realidad es que este tipo de actividades es considerado como "asunto de mujeres", por lo que el impacto entre ellos fue mínimo. En cuatro de los cinco talleres el número de varones fue reducido (Cuadro 1).

En el Cuadro 2 clasificamos las respuestas respecto a las principales actividades a las que refirieron se dedican, destacando para las mujeres las labores domésticas no remuneradas, aunque alrededor de $16 \%$ hizo referencia a algún tipo de actividad generadora de ingresos.

El promedio de edad de las personas participantes fue de 41.6 años. La inclusión de todos los grupos etarios fue de vital importancia, de ahí que durante los talleres haya habido presencia tanto de personas adultas mayores como de los jóvenes. Respecto a la escolaridad, la mitad de quienes asistieron a capacitarse cuentan con estudios de educación media (Cuadro 3).

\section{La planeación de la capacitación}

En 2012 la Administración Municipal 20102013 de San Salvador Tzompantepec, dirigida por una mujer como Presidenta Municipal, solicitó a la Universidad Autónoma de Tlaxcala (UATx), en específico al Cuerpo Académico: Estudios de Género, Educación y Juventud, la aplicación de una consultoría para conducir acciones de capacitación previamente aprobadas en el Proyecto "Transformando Tzompantepec con igualdad entre hombres y mujeres" en el marco de las acciones del Fondo para el Desarrollo de las Instancias Municipales de las Mujeres (FODEIMM), financiado por el Instituto Nacional de las Mujeres (INMUJERES).

El equipo consultor se integró por cuatro facilitadoras y cuatro personas de apoyo, las primeras
Cuadro 2. Actividades económicas de participantes. Table 2. Participants' economic activities.

\begin{tabular}{lccc}
\hline Ocupación & Hombres & Mujeres & Total \\
\hline Obrera & 0 & 1 & 1 \\
Trabajo doméstico & 0 & 57 & 57 \\
Oficios & 1 & 1 & 2 \\
Empleada & 0 & 6 & 6 \\
Campesino & 3 & 0 & 3 \\
Profesión & 0 & 1 & 1 \\
Comerciante & 0 & 3 & 3 \\
Estudiante & 0 & 6 & 6 \\
No contestó & & 1 & 1 \\
\hline Total & 4 & 76 & 80 \\
\hline
\end{tabular}

Fuente: elaboración propia con base en trabajo de campo (2012).

- Source: authors' elaboration based on field work (2012).

The average age of the people who participated was 41.6 years. Including every age group was of vital importance, so that during the workshops there was the presence both of older people and young people. In terms of schooling, half of those who attended the trainings have secondary education studies (Table 3).

\section{Training planning}

In 2012, the 2010-2013 Municipal Administration in San Salvador Tzompantepec, led by a woman as a municipal president, requested from the Autonomous University of Tlaxcala (UATx), specifically from the Academic Corps: Gender, Education and Youth

Cuadro 3. Escolaridad de participantes.

Table 3. Participants' schooling.

\begin{tabular}{lccc}
\hline Nivel & Hombres & Mujeres & Total \\
\hline Sin estudios & 0 & 3 & 3 \\
Primaria & 1 & 17 & 18 \\
Secundaria & 3 & 37 & 40 \\
Bachillerato & 0 & 9 & 9 \\
Licenciatura & 0 & 7 & 7 \\
Carrera trunca & 0 & 1 & 2 \\
No contestó & 0 & 2 & 1 \\
\hline Total & 4 & 76 & 80 \\
\hline
\end{tabular}

Fuente: elaboración propia con base en trabajo de campo (2012). - Source: authors' elaboration based on field work (2012). 
formadas en su mayoría con perspectiva de género. La construcción de una Agenda Ciudadana era el producto obligado por el organismo financiador. Para diseñar este instrumento el grupo capacitador optó por generar una consulta ciudadana alejada de instrumentos tradicionales, como la encuesta de opinión o el sondeo, y eligió trabajar con la propia experiencia de la población a través de cinco talleres de capacitación. Cada taller cubría como mínimo tres horas por sesión y hasta un máximo de cuatro horas.

El diseño de la carta descriptiva, las actividades y la sistematización de los productos elaborados por las y los talleristas fue responsabilidad del equipo consultor, mientras que al Instituto Municipal de las $\mathrm{Mu}$ jeres (IMM-Tzompantepec) $)^{3}$ le correspondió la labor de difundir e invitar a la población a participar en los talleres. De manera conjunta se decidió que la formación iría dirigida a grupos de mujeres y hombres que tuvieran deseos de adquirir nuevos aprendizajes, sin necesidad de que fueran beneficiados por algún programa de apoyo social municipal, estatal o federal.

El grupo facilitador consideró que la capacitación estaba orientada a iniciar un proceso de sensibilización y construcción de canales de comunicación sobre temas que vulneran la dignidad de las personas; por tanto, un principio ético era involucrar sólo a personas interesadas en aprender y no que quisieran participar como respuesta a medidas de imposición, chantaje o condicionamiento para recibir beneficios a través de programas gubernamentales. Sin embargo, al menos en dos talleres las personas asistentes fueron "invitadas" por ser beneficiarias del Programa Federal Oportunidades; esta aceptación fue asumida por el IMM-Tzompantepec.

Se decidió que la capacitación se impartiría directamente en las poblaciones donde el taller se desarrollaría, evitando de esta forma el traslado de las personas participantes y el pago de transportación, siempre difícil de tener. Para favorecer el aprendizaje se solicitó que el número de asistentes no fuera mayor a veinticinco; sin embargo, la mayoría de mujeres acudió con pequeños y pequeñas a cargo, lo cual dejó una lección: las capacitaciones deben contemplar un espacio lúdico para infantes, de tal manera que quienes acudan puedan mantener una escucha atenta que resulta casi imposible, partiendo de que las situaciones de vida de las mujeres no les permiten dejar "fuera de sí" las preocupaciones y obligaciones tradicionales de género.
Studies (Cuerpo Académico: Estudios de Género, Educación y Juventud), the application of consulting to lead training actions previously approved in the project "Transforming Tzompantepec with equality between men and women" (Transformando Tzompantepec con igualdad entre hombres y mujeres) within the framework of the Fondo para el Desarrollo de las Instancias Municipales de las Mujeres (FODEIMM), financed by the National Women's Institute (Instituto Nacional de las Mujeres, INMUJERES).

The consulting team was made up of four trainers and four supporting people, the first mostly trained with gender perspective. The construction of a Citizen's Agenda was the product requested by the financing organization. To design this instrument, the training group opted for generating a citizen's survey different from traditional instruments, such as the opinion survey or poll, and chose to work with the population's own experience through five training workshops. Each workshop covered at least three hours per session, and up to a maximum of four hours.

The design of the descriptive chart, activities and systematization of products elaborated by the workshop attendees was the responsibility of the consulting team, while the Instituto Municipal de las Mujeres (IMM-Tzompantepec) ${ }^{3}$ had the task of divulging and inviting the population to participate in the workshops. In a joint manner, it was decided that the training would be directed towards groups of men and women who had the desire to attain new learning, without the need of them being benefitted by a program of municipal, state or federal support.

The facilitating group considered that the training was directed towards beginning a process of gaining awareness and the construction of communication channels regarding issues that violate people's dignity; therefore, an ethical principle was to involve only people interested in learning and who did not want to participate as a response to measures of imposition, blackmail or conditioning to receive benefits through government programs. However, at least in two workshops the people who assisted were "invited" because they were beneficiaries of the Oportunidades federal program; accepting this was taken on by the IMM-Tzompantepec.

It was decided that the training would be offered directly in the populations where the workshop would take place, thus avoiding the travel and 
Inicialmente, los horarios propuestos para realizar las actividades formativas seguían normas institucionales pero, reconociendo las tareas que comprometen la cotidianeidad y responsabilidades de género asociadas a las mujeres (hora de entrada a la escuela, entrega del almuerzo a maridos o visitas médicas, entre otros), estos horarios fueron modificados y adecuados a sus tiempos. No obstante, las asistentes no dejaban de mostrar "su nerviosismo por ir a hacer el quehacer en la casa”. Si bien la llegada de las mujeres a los talleres era bastante de prisa, al paso de cada actividad olvidaban cuánto tiempo habían permanecido en la formación.

\section{El plan de capacitación}

El objetivo normativo exigido por la instancia financiadora para la capacitación fue: promover y fortalecer el desarrollo humano y local, así como el conocimiento pleno de las mujeres sobre los derechos humanos, el acceso a oportunidades, recursos, servicios y el ejercicio de la libertad, en el proceso de difusión y enriquecimiento de las propuestas de política pública local para la igualdad de género. Para alcanzar este propósito se dividió la capacitación en siete momentos, siempre con la intención de que los contenidos fueran expuestos con el uso de técnicas lúdicas y vivenciales, tomando como guía los principios básicos de la educación popular.

Se exploraron los siguientes temas centrales: derechos humanos y de las mujeres, violencia de género, ciudadanía y desarrollo local, y formación de redes de apoyo comunitarias. La intención fue que las personas participantes percibieran en qué medida se vinculaban entre sí para potenciar el ejercicio pleno de la ciudadanía.

El momento de la apertura ayudó a sensibilizar al grupo, generar un ambiente de confianza, establecer vínculos de respeto y apoyo, y estimular el interés. Cada sesión temática contó con un espacio de reflexión dirigido por las facilitadoras, el cual hizo posible que se pudieran confrontar las vivencias de las talleristas, amigas o parientes cercanas con los nuevos conocimientos adquiridos. Al final del taller se abrió un espacio para meditar colectivamente acerca de las alternativas y soluciones para enfrentar sus realidades y los compromisos que a partir de ese momento cada participante asumía para conducir su propia vida. transportation payment of people who participated, which is always difficult to have. In order to foster learning, it was required for the number of assistants to be lower than twenty-five; however, most women attended with young boys and girls, which served as a lesson: trainings should include a playground for children, so that those who attend can listen attentively, which is almost impossible, stemming from the living situations of the women that do not allow them to leave the traditional worries and obligations of the gender "outside of themselves".

Initially, the schedules proposed to carry out the formative activities would follow institutional norms; however, after recognizing the tasks that daily life and responsibilities implicate for the gender associated to women (time for school entry, delivering lunch to husbands or doctor's appointments, among others), the schedules were modified and adapted to their time available. Nevertheless, attendees did not cease to show "their nervousness over leaving to perform their household chores". Although the arrival of women to the workshops was rather hurried, as the activities advanced, they would forget how long they had remained in the training.

\section{The training plan}

The normative objective demanded by the financing instance for the training was: to promote and strengthen human and local development, as well as the full understanding of women regarding human rights, access to opportunities, resources, services and the exercise of freedom, in the process of divulging and enriching the local public policy proposals for gender equality. In order to reach this purpose, the training was divided into seven moments, always with the intention for the contents to be exposed with the use of playful and experiential techniques, taking as a guide the basic principles of popular education.

The following central themes were explored: human rights and women, gender violence, citizenship and local development, and formation of networks of community support. The intention was for participating people to perceive to what measure they were connected in order to strengthen the full exercise of citizenship.

The moment of opening helped to raise awareness, generate an environment of trust, establish connections 
En el Cuadro 4 se expone la carta descriptiva manejada en la aplicación de los talleres; sin embargo, dependiendo de las características y del número de talleristas se decidía si el orden y la secuencia eran respetados o se modificaban.

\section{El desarrollo de la capacitación}

El equipo facilitador trató de enlazar la planeación de cada formación, considerando tres elementos: la metodología, los recursos didácticos y los contenidos temáticos. A continuación exponemos las actividades desarrolladas en los talleres.

En la actividad "Así vivimos las mujeres de la comunidad", se abordó el tema de Derechos Humanos y Derechos de las Mujeres; se utilizó como pregunta para la reflexión colectiva: ¿Qué hacen los hombres y qué hacen las mujeres en su localidad? Algunas respuestas fueron:

Yo a veces le ayudo a mi esposo a juntar pastura y a cargarla porque él ya está grande, entonces lo tengo que apoyar un poco (Mujer, San Juan Quetzacoalpan).

Lo que hacen las mujeres es el quehacer de la casa; estamos en un área donde se realizan actividades agrícolas y ganaderas, y también las mujeres se dedican a eso (Mujer, San Salvador Tzompantepec).

Varía mucho, hay veces que el campo ya no alcanza y pues se van a trabajar a diferentes lugares. Los hombres buscan trabajo y las mujeres se quedan en la casa con los animales en lo que el marido sale, además de apoyarlos también con lo que se necesite en la casa. Aunque yo ya no trabajo en el campo y no tenga tiempo, una tiene que hacer el trabajo tanto de los hijos como del quehacer de la casa (Mujer, San Salvador Tzompantepec).

El señor se va a trabajar y la mujer se queda $y$, aunque ella no quiera, tiene que hacer las cosas del hogar (Mujer, San Juan Quetzacoalpan).

El comentario expresado en el último testimonio es una opinión generalizada entre las participantes. Recordemos que la mayoría no realiza trabajos asalariados, por lo que el perfil de las talleristas puede considerarse en el marco de esquemas tradicionales of respect and support, and stimulate interest. Each thematic session had space for reflection directed by the trainers, which made it possible for them to confront the experiences of workshop assistants, friends or close relatives with the new knowledge acquired. At the end of the workshop there was space to meditate collectively about the alternatives and solutions to face the realities and commitments that each participant assumed from that moment forward, to lead her life.

Table 4 shows the descriptive chart used in the workshops; however, depending on the characteristics and number of workshop attendees it was decided whether the order and sequence were respected or modified.

\section{Developing the training}

The training team tried to link the planning of each session of training by considering three elements: the methodology, the didactic resources, and the thematic contents. Next, we present the activities carried out in the workshops.

In the activity, "This is how we, women of the community, live", the subject of Human Rights and Women's Rights was approached; the following was used as question for collective reflection: What do men do and what do women do in your locality? Some of the answers were:

I sometimes help my husband to gather grass and carry it because he's older, so I have to help him a little (Woman, San Juan Quetzacoalpan).

What women do is household chores; we are in an area where agricultural and livestock activities are performed, and women also devote their time to that (Woman, San Salvador Tzompantepec).

It varies a lot; sometimes the field is not enough, so they go to work in different places. The men search for work and the women remain at home with the animals while the husband is out, in addition to helping them also with what is needed at home. Although I don't work the field anymore, and don't have any time, I must do the work both with the children and the household chores (Woman, San Salvador Tzompantepec). 
Cuadro 4. Organización de los talleres. Table 4. Workshop organization.

\begin{tabular}{lll}
\hline Temática & Objetivo & Dinámica \\
\hline Bienvenida, presentación y encuadre & $\begin{array}{l}\text { Presentar la temática y dinámica del taller, } \\
\text { así como al equipo facilitador }\end{array}$ & $\begin{array}{l}\text { El equipo facilitador se presenta ante las } \\
\text { personas asistentes; se establece la temática } \\
\text { a desarrollar y la dinámica que se empleará. } \\
\text { Se dan a conocer algunas reglas básicas para }\end{array}$ \\
& & que opere y funcione el trabajo.
\end{tabular}

Así vivimos las mujeres de la comunidad

Tema obligatorio:

Derechos humanos y de las mujeres
Que las personas asistentes expresen a través de dibujos si en sus comunidades se hacen valer y respetar los derechos humanos, en particular de las mujeres; de no ser así, reflexionar en qué situaciones y circunstancias los derechos son quebrantados
- El equipo facilitador induce a la reflexión, apoyándose de la imaginería; posteriormente pide a las personas asistentes (puede ser por grupos) proyecten en un dibujo lo que ven, escuchan y/o viven respecto al respeto de los derechos humanos en su comunidad.

- Se les entrega un cuadernillo que contiene los derechos humanos.
Cuentos que no son cuentos... si me los cuentas seguro te los creo

Temas obligatorios:

Derechos humanos y de las mujeres Violencia de género
Que las personas asistentes conozcan los derechos humanos y de las mujeres. Se enfatiza en la situación y condición de las mujeres en relación con la violencia de género, a la desigualdad en el acceso a los espacios públicos (educativos, laborales, políticos, sociales), a los recursos y a la toma de decisiones
- El equipo facilitador narra dos cuentos: uno clásico, adaptado a la realidad y contexto actual y, el otro, un cuento alternativo -que rompe los estereotipos de género-. En ambos se intenta identificar las situaciones, condiciones y trasgresiones posibles que se hacen a los derechos humanos y particularmente a los derechos de las mujeres. Simultáneamente se pegan carteles de los derechos humanos.

- Enseguida por grupos eligen un cartel y platican sobre el significado del derecho.

- Posterior a ello, las facilitadoras hacen una presentación sobre el tema, aclarando dudas y promoviendo la reflexión.

¿Quién hace qué?

Tema obligatorio:

Ciudadanía y desarrollo local
Que las personas asistentes reconozcan el trabajo reproductivo, productivo y comunitario desarrollado por mujeres y hombres, y el impacto en el desarrollo de la comunidad y el municipio, y reconocer que el ejercicio de la ciudadanía no es exclusivo de los varones
- El equipo facilitador entrega a las personas participantes recortes que muestren diferentes ámbitos, espacios y tipos de trabajos que realizan hombres y mujeres. Se ubican al centro, deben clasificarlos según sea el tipo de trabajo y de acuerdo con quien lo realice (mujeres, hombres o ambos). Se colocan tres papelógrafos en la pizarra: uno con la silueta de un hombre, otro con la de una mujer y otro con la de ambos. Los recortes serán colocados en uno u otro lugar, según lo que el grupo vaya determinando durante el proceso. Se presentan los trabajos en plenaria.

- El equipo facilitador remarca la importancia de la contribución de las mujeres al desarrollo local y la oportunidad que ésta representa para el ejercicio de la ciudadanía 
Cuadro 4. Continuación.

Table 4. Continued.

\begin{tabular}{lll}
\hline Temática & Objetivo & Dinámica \\
\hline Ojos que no ven... el corazón lo resiente & $\begin{array}{l}\text { Que las personas asistentes reflexionen } \\
\text { sobre la importancia de crear y mantener }\end{array}$ & $\begin{array}{l}\text { personas asistentes y se les vendan los ojos; } \\
\text { redes de apoyo comunitario para el forta- } \\
\text { deben caminar de un extremo a otro (sali- } \\
\text { Tema obligatorio: }\end{array}$ \\
$\begin{array}{ll}\text { Formación de redes de apoyo comunita- } \\
\text { rias }\end{array}$ & & $\begin{array}{l}\text { da-meta). El resto dará palmadas (una pal- } \\
\text { mada a la derecha, dos a la izquierda, tres } \\
\text { al frente, cuatro hacia atrás) para ir guiando }\end{array}$ \\
& $\begin{array}{l}\text { a quien tiene los ojos vendados, sin dejarse } \\
\text { tocar. Pasados algunos minutos, quienes no }\end{array}$ \\
& $\begin{array}{l}\text { lograron llegar a la meta serán conducidas } \\
\text { por el grupo. }\end{array}$ \\
& $\begin{array}{l}\text { - Las facilitadoras inducen a la reflexión, } \\
\text { enfatizando la importancia de la ciudada- } \\
\text { nía y las redes de apoyo entre ésta para pro- } \\
\text { mover el desarrollo y bienestar personal y }\end{array}$ \\
& de la localidad
\end{tabular}

Evaluación y cierre

Las personas asistentes compartan lo aprendido durante la jornada de trabajo, expresen cómo se sienten (emociones) respecto a lo que se trabajó y, finalmente, con una palabra indiquen cómo se van y cuáles son sus metas

Source: authors' elaboration based on field work (2012).

y heteronormativos de género. La distribución tradicional de actividades según sexo estructura estereotipadamente la división sexual del trabajo, donde los hombres se dedican a actividades económicas y las mujeres a tareas que reproducen la economía de cuidado; ninguna mencionó su participación en la comunidad.

Las respuestas a la pregunta de reflexión fueron manifiestas a través de dibujos elaborados por ellas mismas, recortes de revistas o comentarios verbales. Las facilitadoras enfatizaron el igual valor que tiene el trabajo de las mujeres al contribuir a la reproducción de otros seres humanos y el resto de actividades económicas remuneradas. Se estimuló a las mujeres a auto-reconocer sus aportes y valorarlos.

En la actividad "Cuentos que no son cuentos... si me los cuentas seguro te los creo", que comprometía el tema de Derechos Humanos, Derechos de las Mujeres y Violencia de Género, se dio lectura a varios relatos. Entre ellos la narración de "Mario un machista arrepentido", que trató sobre las actitudes machistas de los hombres hacia las mujeres en el plano familiar. La historia cuenta la difícil situación que una madre enferma enfrenta y cuyo padecimiento la obligó a estar postrada en cama; es hasta ese momento en que ellos (pareja e hijos) se dan cuenta de la indiferencia que mostraban frente a todas las obligaciones socialmente impuestas a su madre.
The man goes to work and the woman stays and, even if she doesn't want to, she has to do the household chores (Woman, San Juan Quetzacoalpan).

The comment expressed in the last testimony is a generalized opinion among participants. Let us remember that most of them do not have paid work, so the profile of workshop assistants can be considered within the framework of traditional and heteronormative gender schemes. The traditional distribution of activities according to sex stereotypically structures the sexual division of labor, where men are devoted to economic activities and women to tasks that reproduce the care economy; not one mentioned her participation in the community.

The answers to the reflection question were manifest through drawings done by the women themselves, with magazine cut-outs or verbal comments. The trainers emphasized the equal value that work by women has when contributing to the reproduction of other human beings, and other paid economic activities. Women were stimulated to recognize their contributions and to value them.

In the activity "Stories that are not stories...if you tell them to me, I'm sure I'll believe you", which approached the issue of Human Rights, Women's 
Una respuesta al unísono retumbó ante el cuestionamiento de reflexión ¿Qué enseñanza les dejó el cuento? "Todas somos Marías" (Varias voces, San Juan Quetzacoalpan) o el eco escuchado en otra localidad: "[Como María] uno vive todos los días lo mismo, eso pasa con los esposos" (Mujer, San Juan Quetzacoalpan). De manera colectiva se reafirmó la importancia de que ellas sean respetadas, actúen frente a situaciones de violencia y discriminación, y aprendan que sus aportaciones a la cotidianeidad en el hogar son indispensables para la sobrevivencia. Celarié et al. (2008:77) mencionan que "el proceso organizativo da oportunidad a que las mujeres se reúnan, compartan nuevos espacios en el ámbito educativo a través de la capacitación, nuevos roles en los espacios públicos y en lo privado una mirada distinta del valor social que tiene el trabajo doméstico".

En otras localidades se optó por la lectura de un cuento alternativo con perspectiva de género: "La Tarzana". Esta historia narra la violación de los siguientes derechos de las mujeres: el derecho a la propiedad, a ser elegida para ocupar algún cargo público y a la no discriminación en razón del sexo. El cuento describe que en la selva patriarcal los animales deben elegir un nuevo rey y, ya que Tarzán era viejo, tenía que suceder los derechos del trono a su descendencia pero, como él tenía una hija, el resto de los animales se negaban, poniendo "a cumplir varias pruebas a Tarzana" lo que, a decir de las talleristas, ocurre con bastante frecuencia en su contexto:

Podemos ver claramente cómo Tarzán tenía la función de cuidar la selva. Pero no tuvo hijo, sino hija y fue ella la que tuvo que ir adquiriendo la capacidad para desarrollar esas actividades, además de tener la visión de continuar con el trabajo de su papá, y así lo asumió. Cuando le dijeron que tenía que quedarse con el trabajo de su papá, ella dijo: "por qué no, si yo me he estado preparando para eso". Aunque no se lo dijo a nadie, ella ya había estado trabajando para desarrollar esas habilidades (Mujer, San Andrés Ahuashuatepec).

Cuando nos dejan a los hijos, ¿quién los ve? Pues nosotras, y aun así no se nos reconoce nuestro trabajo. Así, en el cuento ella [la Tarzana] hace muchas pruebas para comprobar que puede realizar lo que hace un hombre (Mujer, San Andrés Ahuashuatepec).
Rights and Gender Violence, they read several stories. Among them, they read the story of "Mario, a macho with regrets", which dealt with the macho attitudes of men towards women in the family scope. The story narrates the difficult situation faced by a sick mother, whose illness forced her to be in bed; it was not until that moment when they (spouse and children) realized the indifference they showed in face of all the obligations that are socially imposed on the mother.

A response in unison resounded when the reflective question was asked: What lessons did the story leave you? "We are all Marías" (Several voices, San Juan Quetzacoalpan) or the echo heard in another locality: "[Like María] we go through this every day, this is what happens with the husbands" (Woman, San Juan Quetzacoalpan). Collectively, the following was reaffirmed: the importance of them being respected, acting against situations of violence and discrimination, and learning that their contributions to daily life in the household are essential for survival. Celarié et al. (2008:77) mention that "the organizational process allows for women to come together, share new spaces in the educational scope through training, new roles in public spaces, and in private, to have a different viewpoint of the social value that domestic work has".

In other localities they opted for reading an alternative story with gender perspective: "The Tarzan Woman". This story narrates the violation of the following rights of women: the right to property, to be elected to occupy a public position, and to non-discrimination as a result of their sex. The story describes that in the patriarchal jungle the animals must choose a new king and, since Tarzan was old, he had to give up his rights to the throne to his descendants but, since he only had a daughter, the rest of the animals refused, making "the Tarzan woman go through several trials", which, according to the workshop attendees, happens quite frequently within their context:

We can see clearly that Tarzan had the function of caring for the jungle. But he didn't have a son, but rather a daughter, and it was she who had to acquire the ability to develop those activities, in addition to having the vision to continue with her father's work, and that's how she assumed it. When she was told that she had to keep her 
Tarzana superó todas las exigencias que le pidieron. Al final ella es valorada por la jungla y se convierte en soberana: sucesora de patrimonio, poseedora del poder público y reconocimiento de "las extrańas especies en la selva”. Algunos de los comentarios de las talleristas fueron:

Oiga usted, a veces los padres tienen terrenos. En el caso de mi familia fuimos muchos hijos y entonces el nuestro nomás le dejó a los hombres, pero a nosotras no (Mujer, Xaltianquisco).

Yo pienso que debemos proteger más a nuestras hijas, o sea, a las mujercitas porque luego las dejan y ellas son las que andan rodando con sus hijos, porque ellos (hombres) luego se van y dejan a la mujer o se van con otra, pero ellos siempre son los que mandan y nosotras nos quedamos ahora sí que desamparadas. Eso es lo que nosotras deberíamos de ver como mujeres, ver por nuestras hijas, que tengan un patrimonio, y ya si el marido las deja o no, ellas por lo menos tienen su casa (Mujer, Xaltianquisco).

Antes nos decían: para qué vas a estudiar si al final te vas a casar y te van a mantener, pero al hombre pues no porque él tenía que estudiar y trabajar porque iba a mantener a la mujer (Mujer, San Mateo Inophil).

Algunas de las talleristas dijeron que sí habían heredado tierra, pero la mayoría lo negó. Un número importante precisó que solamente los hermanos recibieron patrimonio de esta manera, ya que la norma cultural dice que los hombres son quienes trabajan más y en algún momento serán jefes de familia, por lo que lo necesitan más, situación bastante similar a la de otros lugares del estado de Tlaxcala (Flores, 2010).

En otras localidades se leyeron cuentos tradicionales y la reflexión se centró en los papeles asignados a las mujeres: dependientes siempre de otros personajes (el príncipe, el rey), violentadas por otros (la bruja, el ogro) y prisioneras (castillos, cuevas, chozas, fondo del mar), mientras que los papeles masculinos se posicionaban como héroes, reyes, salvadores y poseedores de riquezas y de poder.

El contacto previo con las poblaciones indicaba el desconocimiento sobre el tema de los derechos humanos y, en particular, de los de las mujeres. Después father's job, she said: "why not, if I've been preparing for that?" Even if she didn't tell anyone, she had already been working to develop those abilities (Woman, San Andrés Ahuashuatepec).

When we are left with the children: who takes care of them? Well, we do, and even so our work is not recognized. So, in the story she (the Tarzan woman) undergoes many trials to prove that she can do what a man does (Woman, San Andrés Ahuashuatepec).

The Tarzan Woman outperformed all the demands that they asked of her. At the end, she is valued by the jungle and she becomes ruler: successor to the patrimony, possessor of public power, and with recognition from "the strange species in the jungle". Some of the comments from the workshop attendees were:

Hey, you, sometimes the fathers have lands. In the case of my family, we were many children and then our father only left them to the males, but not to us (Woman, Xaltianquisco).

I think that we have to protect our daughters more, that is, the women, because sometimes they are abandoned and they are the ones who are around with their sons, because they (the men) sometimes leave the woman or go with another one, but we should see as women, take care of our daughters, so they have patrimony, and so if the husband leaves them or not, at least they already have their home (Woman, Xaltianquisco).

Before they used to say: what are you going to study for, if in the end you will get married and he will support you; but not the man, because he had to study and work because he was going to support his wife (Woman, San Mateo Inophil).

Some of the workshop attendees said they had inherited land, but most of them denied it. An important number specified that only their brothers received patrimony in this way, since the cultural norm says that it is the men who work more and at some point will be heads of households, so they need more, a situation that is quite similar to other places in the state of Tlaxcala (Flores, 2010). 
de concluir las dos primeras temáticas, las talleristas pudieron reconocer los siguientes derechos como elementales: vivir libre de violencia, expresarse, defenderse, participar en la política, tener igualdad, tolerancia, respeto y derecho a la propiedad y a una vivienda digna, así como tener derecho a la libertad, la salud y la educación. Para cerrar esta actividad se formuló la siguiente pregunta de reflexión: ¿Por qué las mujeres tenemos un conjunto de derechos? La respuesta al unísono fue "Porque los hombres no nos respetan" (Varias voces, San Mateo Inophil). La realidad de las talleristas es que desconocen sus derechos y carecen de alternativas o recursos para ejercerlos.

Esta afirmación colectiva orientó a introducir a la siguiente actividad del taller "Ojos que no ven... el corazón lo resiente", partiendo de la siguiente pregunta de reflexión: ¿Para qué sirve a las mujeres la organización y la formación de redes? Se concluyó que el trabajo colectivo de las mujeres permite establecer relaciones de solidaridad, que no se sientan solas ni aisladas, y motiva a escuchar, aprender a respetar, guiar ordenadamente, estar atentas y tratar de apoyar a la otra (la que está vendada de los ojos, pero sin entorpecer su proceso individual). Además, se reflexionó que una vez que han identificado sus derechos, tienen que ejercerlos, es decir, "ponerlos en práctica".

La conformación de redes representa una alternativa de organización que apoya este fin, así como la participación, la conciliación de intereses, la puesta en común de necesidades, "la búsqueda de ayuda de instancias locales que apoyen la situación de las mujeres", el "protestar hasta que nos hagan caso cuando nos damos cuenta que aprietan nuestra dignidad". En conjunto, ello conduciría de forma conveniente al proceso de asumirse ciudadana. Se concluyó que una forma de comenzar a hacerlo era demandar la colaboración de las autoridades locales para generar soluciones coordinadas a las problemáticas sentidas por las mujeres y sus familias.

Finalmente, la actividad "De propuesta en propuesta algo hemos de lograr" cerraba quebrando una piñata que contenía una serie de propuestas que intentaban responder no solo a necesidades prácticas de género, sino a intereses estratégicos de género; éstas se planteaban en plenaria y cada una era votada para sugerirse ante las autoridades locales y municipales correspondientes, según su prioridad.

Para promover formas de expresión que permitieran explicar sus diversas realidades y experiencias
In other localities traditional stories were read, and the reflection was centered on the roles assigned to women: always dependent on other characters (the prince, the king), violated by others (the witch, the ogre), and prisoners (castles, caves, huts, bottom of the ocean), while the masculine roles were positioned as heroes, kings, saviors and owners of wealth and power.

The previous contact with the populations indicated the ignorance regarding the issue of human rights, and particularly of women. After concluding the first two themes, the workshop attendees could recognize the following rights as elemental: living free of violence, expressing themselves, defending themselves, participating in politics, having equality, tolerance, respect and the right to property and dignified housing, as well as having the right to freedom, health and education. To close that activity, the following reflection question was formulated: Why do women have a set of rights? The answer, in unison, was: "Because men do not respect us" (Several voices, San Mateo Inophil). The reality of workshop attendees is that they ignore their rights and lack alternatives or resources to exercise them.

This collective statement was directed towards introducing the next activity in the workshop: "Eyes that do not see...the heart resents it", stemming from the following reflection question: What is the use of organization and network formation for women? It was concluded that women's collective work allows them to establish solidarity relationships, to not feel lonely or isolated, and motivates them to listen, learn to respect, guide in order, be aware and try to support each other (the one with eyes covered, although without hindering her individual process). Also, they reflected that once they have identified their rights, they must exercise them, that is, "put them in practice".

Establishing networks represents an organizational alternative that supports this goal, as well as participation, conciliation of interests, making needs common, "the search for help from local instances that support women's situation", "protesting until we are heard when we realize that they are crushing our dignity". As a whole, this would lead to the process of becoming a citizen in a convenient manner. It was concluded that one way of beginning to do it was to demand the collaboration from local authorities to generate coordinate solutions to the problems experienced by women and their families. 
cotidianas en todos los talleres y actividades, se recurrió al uso de técnicas lúdicas y recursos didácticos accesibles para las mujeres: recortes, proyecciones gráficas, dibujos, carteles, manejo del cuerpo, lecturas de cuentos. En particular, romper la piñata generó entusiasmo y desinhibición corporal entre las personas participantes, lo que de cierta manera "animaba" su realidad y con orgullo o preocupación la compartían al ritmo de dale, dale, dale.

\section{Dilemas en el proceso de capacitación}

Durante el proceso de formación distinguimos limitaciones relacionadas entre sí que tuvieron que ver con los tiempos programados para realizar el taller y los horarios, los ejes temáticos y la participación. Si bien los temas cumplían con la obligatoriedad del proyecto, el tiempo destinado para cada actividad fue insuficiente para abordar con profundidad cada uno. Cerlarié et al. (2008) exponen una situación muy similar.

En los cinco talleres se rebasó el tiempo programado pues, a pesar del interés que mostraron las participantes, ellas solo pudieron compartir cuatro horas como máximo en éstos. Además, se destaca que las que asistieron no habían sido previamente informadas sobre el objetivo del mismo, debido a que el IMMTzompantepec no realizó una campańa adecuada de promoción y porque no existió ninguna condicionante para asistir más que su propia voluntad. Es necesario mencionar que el horario en el que se ofrecieron los talleres interfería en el desarrollo de sus actividades cotidianas (quehacer doméstico, preparación de alimentos, compras, entrega de almuerzos a esposos o hijas e hijas, asistencia a servicios de salud, juntas escolares y salida de infantes de las escuelas, entre otras); por esta razón, dos de los talleres se reprogramaron.

Consideramos que, no sólo en términos de número de participantes, la convocatoria pudo tener mejor respuesta si el IMM-Tzompantec hubiera mantenido un acercamiento estrecho con mujeres y hombres líderes, autoridades locales o informantes clave; sin embargo, se reconoció que no existe una plataforma de acción que estimule la participación comunitaria y permita fincar vínculos y acuerdos entre institución (gobierno municipal) y comunidad (las mujeres). Martínez y Díaz (2005) refieren que la capacitación de género resulta más fácil cuando se detectan mujeres líderes y sensibles a los problemas de sus compañeras. Además, creemos que las autoridades locales
Finally, the activity of "From proposal to proposal, we will achieve something" closed with breaking a piñata that contained a series of proposals that attempted to give answer not only to practical gender needs, but to strategic gender interests; these were suggested in a plenary session and each one was voted to be presented to the corresponding local and municipal authorities, depending on their priority.

To promote forms of expression that would allow explaining their diverse realities and daily experiences, in all the workshops and activities, they resorted to playful techniques and didactic resources accessible to the women: cut-outs, graphic projections, drawings, posters, body use, reading stories. Breaking the piñata, in particular, generated enthusiasm and bodily lack of inhibition among participant people, which somehow "animated" their reality and with pride or preoccupation they shared it to the rhythm of dale, dale, dale.

\section{Dilemmas during the training process}

During the training process we found limitations related among themselves that had to do with the times programmed to carry out the workshop and the schedule, the thematic axes and the participation. Although the themes complied with the obligatory part of the project, the time destined to each activity was insufficient to approach each one in depth. Cerlarié et al. (2008) expose a very similar situation.

During the five workshops the time programmed was exceeded, since in spite of the interest that participants showed, they could only share four hours as a maximum during them. Also, it stands out that those who attended had not been previously informed about its objective, because the IMM-Tzompantepec did not carry out an adequate promotion campaign and because there was no determinant to attend other than their own will. It should be mentioned that the schedule when the workshops were offered interfered with the development of their daily activities (house chores, preparing food, shopping, delivering lunch to husbands and children, attending health services, school meetings and picking up children from schools, among others); therefore, two of the workshops were reprogrammed.

We consider that the invitation could have had a better response, not only in terms of the number of participants, if the IMM-Tzompantec had 
(presidencias de comunidad) tampoco tuvieron disposición para convocar.

Es importante precisar que cualquier planeación de capacitación debe contemplar las expectativas de formación y disponibilidad por parte de las personas asistentes, de tal manera que la formación o los contenidos del taller correspondan a las necesidades y dinámicas de los grupos. Lo contrario solo significa capacitar para "cumplir un programa de actividades" que en ocasiones limita y entorpece la expresión y el conocimiento de las formas de pensar y las opiniones de las personas capacitadas. El equipo facilitador intentó respetar la planeación, pero la diversidad y la especificidad de cada grupo condujo a comprender y atender el tiempo requerido por las mujeres para poder compartir y socializar dudas y expresar inquietudes.

Esta acción demostró que los espacios de intercambio de experiencias para las mujeres son escasos y que aún hace falta un arduo trabajo de convencimiento; de ahí la necesidad de considerar otras estrategias que permitan cumplir mínimamente con el reto de la sensibilización, pues el desarrollo de ésta debe iniciar en casa.

Finalmente creemos que el IMM-Tzompantepec, y cualquier instancia que brinde servicios a mujeres, debe olvidarse de "planear desde el escritorio", pues decirle a una mujer "que haga su solicitud por escrito" (personal de IMM) solo incrementa la burocracia y el desperdicio de recursos que provienen y deben ser devueltos a la ciudadanía lo más pronto posible, con calidad humana y con visión de género, colocándose sin lugar a dudas en el "zapato de esas otras que llegan ahí buscando ayuda” (Voces de mujeres).

\section{Conclusiones}

Este trabajo ha tenido como propósito resaltar la importancia de capacitar con perspectiva de género. Hacerlo de otra manera solo logra la asimilación de conocimientos, sin adquirir en profundidad herramientas para la toma de conciencia y la puesta en práctica, asumiendo que cada persona tiene ritmos, momentos, formas y estilos distintos de hacerlo. El acompañamiento en esta experiencia le indica al equipo consultor que debe hacerse desde una posición alejada de preceptos teóricos y esquemas construidos "desde afuera" y con una actitud de reconocimiento de la cotidianeidad, respetando lo que ocurre maintained a close communication with women and men leaders, local authorities or key informants; however, it was recognized that there is no action platform that stimulates community participation and allows establishing connections and agreements between the institution (municipal government) and the community (women). Martínez and Díaz (2005) mention that gender training is easier when women leaders are detected who are also sensitive to their peers' problems. In addition, we believe that the local authorities (community presidency) also didn't have the willingness to make the invitation.

It is important to specify that any training planning should contemplate the expectations of training and availability from the people who attend, so that the training or the contents of the workshop correspond to the needs and dynamics of the groups. Otherwise, it only means training to "fulfill a program of activities" that on occasions limits and impedes the expression and knowledge of the ways of thinking and the opinions of the people being trained. The facilitating team attempted to respect the planning, but the diversity and specificity of each group led to understanding and addressing the time required by the women to be able to share and socialize doubts and express anxieties.

This action showed that the spaces for women to exchange experiences are scarce and that there is still the need for hard work in convincing; thus, the need to consider other strategies that allow complying minimally with the challenge of creating awareness, for its development should begin at home.

Finally, we believe that the IMM-Tzompantepec, and any instance that provides services to women, should forget "planning from the desk", because telling a woman to "hand in her request in writing" (IMM staff) only increases the bureaucracy and waste of resources that come and should be returned to the citizens as soon as possible, with human quality and gender vision, placing themselves without a doubt in the "shoes of the others who come seeking help" (Women's voices).

\section{Conclusions}

This study had the purpose of highlighting the importance of training with gender perspective. Doing it differently only achieves the assimilation of knowledge, without acquiring in-depth tools for developing awareness and putting them into practice, assuming that each person has different rhythms, 
"adentro" de las localidades, así como las vivencias personales de cada participante.

La mirada de género en la capacitación tiene que ir más allá de una consultoría a cumplir, pues formarse desde el género como práctica de vida transita del plano individual hacia la construcción de alternativas y maneras colectivas de vivirse desde uno u otro género. La voluntad propia es significativa, pero la concientización de las poblaciones conduce, sin lugar a dudas, a nutrir voluntades colectivas y ciudadanías conscientes.

Para estimular el ejercicio de la ciudadanía se requiere de la creación de espacios para escuchar y hacer valer las necesidades prácticas y los intereses estratégicos, particularmente de las mujeres: la capacitación en la modalidad de talleres se convirtió en espacio de formación continua y en motor de potenciación. En las formaciones se aprendieron conocimientos, pero al mismo tiempo se compartieron experiencias, en muchas ocasiones similares, que suscitaron la reflexión en los niveles individual y grupal sobre la propia situación de vida y la de la colectividad. En estos espacios se tuvo la oportunidad de indignarse y enojarse frente a las injusticias que resonaban en el foro al escuchar las vivencias de otras personas, quienes se apropiaron del momento, se contagiaron y transmitieron a las y los demás las "ganas de decir, de opinar, de expresarse".

La estrategia de capacitación orientada desde la perspectiva de género en San Salvador Tzompantepec, Tlaxcala contribuyó a:

a) Diseñar una metodología con una didáctica apropiada a los contextos inmediatos y cotidianos.

El trabajo con mujeres y hombres en sus lugares de origen dejó aprendizajes significativos al equipo formador, en particular aquellos que exigen reconsiderar las formas de abordaje de la enseñanza en realidades distintas y diversas. Tener "buenas intenciones" no es suficiente para introducirse a las comunidades, promover cambios y estar firmemente afianzadas en cuestiones de género. Es necesario reconocer que no es a partir de "nuestros ejes" ni de "nuestra experiencia" desde donde se gestionan y movilizan las conciencias; por el contrario, tenemos el pleno compromiso de respetar y considerar las complejas maneras de concebir, vivir, cuestionar y asumir la realidad de parte de las otras personas. moments, forms and styles to do it. Accompanying this experience showed the consulting team that it should be done from a position that is far from theoretical precepts and schemes built "from the outside", and with an attitude of recognition of daily life, respecting what happens "inside" of the localities, as well as the personal experiences of each participant.

The gender point of view in training has to go beyond consulting to be fulfilled, since training from gender as a life practice transits from the individual plane towards the construction of alternatives and collective ways of living from one or the other gender. Individual will is significant, but the awareness of populations leads, without a doubt, to nurturing collective wills and conscious citizenships.

In order to stimulate the exercise of citizenship, the creation of spaces to listen and make use of the practical needs and strategic interests, particularly of women, is required: the training in the modality of workshops became a space for continuous training and a motor for exponentiation. In the trainings knowledge were learned, but at the same time experiences were shared, on many similar occasions, which caused reflection at the individual and group levels regarding their own life situation and the collectivity's. In these spaces there was the opportunity to be outraged and angry about the injustices that resounded in the forum when listening to other people's experiences, taking advantage of the moment, and infecting and transmitting to others the "appetite to say something, have an opinion, to express themselves".

The training strategy directed from the gender perspective in San Salvador Tzompantepec, Tlaxcala, contributed to:

a) Design a methodology with a didactic appropriate to the immediate and daily contexts.

The work with women and men in their places of origin left significant learnings for the training team, particularly those that demand reconsidering the ways to approach teaching in distinctive and diverse realities. Having "good intentions" is not enough to enter the communities, promote change and be firmly secured in gender issues. It is necessary to recognize that it is not stemming from "our axes" or "our experience" where consciousness is managed 
Una fórmula sencilla para lograrlo es permitirse aprender de la otra o del otro, poner disposición para nutrir el proceso de capacitación alejada de marcos referenciales, conceptos, tecnicismos o teorías y no obviar que, si bien las problemáticas son extensas y casi las mismas para todas las mujeres del planeta, también ocurren en "ese sitio" y solo corresponden a quienes ahí habitan. De ahí la importancia de "mostrarlo" a partir de la experiencia y de la vida diaria y, por qué no, dejar huella en todas las personas participantes, incluidas las expertas. Las condiciones y situaciones de desventaja, que histórica y socioculturalmente están presentes en la vida de las mujeres, ocurren en "nuestros" y en sus "contextos", pero solo "desde", "con" y "para" las mujeres se logran los cambios y el reconocimiento pleno de sus libertades, responsabilidades y compromisos como ciudadanas.

b) Establecer estrategias que favorecieran la apropiación del espacio y la valoración del conocimiento cotidiano de las personas participantes.

La capacitación con perspectiva de género aborda temas tan complejos como derechos humanos y de las mujeres, violencia de género, ciudadanía y desarrollo local, y formación de redes de apoyo comunitarias, lo cual obligó a la formulación de una ruta metodológica que partiera de la cotidianeidad y del uso de los sentidos. De ahí la estrategia de recurrir a técnicas de enseñanza-aprendizaje lúdicas donde el uso de herramientas pedagógicas permitió despertar el interés y generar motivación entre las personas asistentes, en particular de las mujeres; al mismo tiempo se logró la recuperación de sus saberes.

c) Desmitificar que en especial las mujeres son incapaces de contener conocimientos y apropiarse de nuevos aprendizajes y, sobre todo, de practicarlos en sus rutinas cotidianas, haciéndolas esto inhábiles de asumirse como ciudadanas.

Una pretensión del grupo facilitador fue estimular entre las personas participantes la capacidad de entender y asumir que son poseedoras de derechos. Para quienes nos comprometemos a capacitar, la experiencia de formación aquí sistematizada indica la importancia de integrar la mirada de género en esta labor; de esta forma, los resultados darán mayores oportunidades para construir una sociedad cada vez and mobilized; on the contrary, we have the full commitment of respecting and considering the complex ways of conceiving, living, questioning and assuming the reality by other people.

A simple formula to achieve it is to allow learning from the other person, being available to nourish the process of training far from referential frameworks, concepts, technical terms or theories, without ignoring that although the problems are extensive and almost the same for all women in the planet, they also happen in "this place" and only correspond to those who inhabit it. From this, the importance of "showing it" from experience and daily life and, why not, leaving a mark on all the people who participate, including the experts. The conditions and situations of disadvantage, which are present historically and socio-culturally in women's lives, occur in "our" and in their "contexts", although only "from", "with" and "for" women are changes achieved and the full recognition of their freedoms, responsibilities and commitments as citizens attained.

b) Establishing strategies that favor the appropriation of space and the valuation of daily knowledge of participating people.

Training with gender perspective approaches such complex issues as human and women's rights, gender violation, citizenship and local development, and the formation of community support networks, which forced the formulation of a methodological route that stemmed from daily life and the use of senses. Therefore, the strategy of resorting to playful teaching-learning techniques where the use of pedagogical tools allowed awakening the interest and generating motivation among the attending people, particularly women, was used; at the same time, a recuperation of their knowledge was also achieved.

c) Demystifying that women, in particular, are incapable of holding knowledge and appropriating new understandings and, above all, of practicing their daily routines, making them unable to assume themselves as citizens.

An aspiration of the facilitating group was to stimulate among the participant people the ability of understanding and assuming that they are holders of rights. For those who are committed to training, 
más igualitaria y digna para las mujeres. En este caso, para quienes son capacitadas, la habilitación puede ser adoptada como la oportunidad para iniciarse en el ejercicio de la ciudadanía permanente, y no solo prestada por tiempos electorales, por ausencia de la pareja u otras razones.

Esta experiencia de capacitación con perspectiva de género permitió, en especial a las mujeres, adquirir $\mathrm{y}$ aprehender herramientas y conocimientos para auto-reconocerse como personas con derechos que las potencia y las posiciona en sus primeros pasos como ciudadanas.

\section{Notas}

${ }^{1}$ Olimpia de Gouges duplica una versión nombrada Declaración de los Derechos de la Mujer y de la Ciudadana en el año 1791. Olimpia de Gouges duplicates a version named Derechos de la Mujer y de la Ciudadana in 1791.

${ }^{2}$ Las autoras como integrantes del Cuerpo Académico (C.A-UATx-195) Estudios de Género, Educación y Juventud del Centro de Investigaciones Interdisciplinarias sobre Desarrollo Regional (CIISDER) agradecen al Programa Estratégico Cuerpos Académicos Calidad y Productividad para su Internacionalización de la Universidad Autónoma de Tlaxcala (CACyPI-UATx-2014) el apoyo para concluir este artículo. The authors, as members of the Cuerpo Académico (C.A-UATx-195) Estudios de Género, Educación y Juventud del Centro de Investigaciones Interdisciplinarias sobre Desarrollo Regional (CIISDER) thank the Programa Estratégico Cuerpos Académicos Calidad y Productividad para su Internacionalización of the Universidad Autónoma de Tlaxcala (CACyPI-UATx-2014) for the support to conclude this article.

${ }^{3} \mathrm{El}$ IMM se creó en el periodo de esta administración municipal y solo tenía como recursos humanos a la titular con estudios en ciencias políticas, una abogada y un psicólogo como prestador de servicio social, en los tres casos con escasa experiencia profesional. En parte, ésta pudo ser la razón por la cual para algunas mujeres era una oficina desconocida e ignoraban los servicios que ofertaba. La administración vigente (2014-2016) no renovó la permanencia de esta oficina. The IMM was created during the period of this municipal administration and only had as human resources the principal with studies the training experience systematized here indicates the importance of integrating the gender viewpoint in this task; thus, the results would give greater opportunities to build an increasingly egalitarian and dignified society for women. In this case, for those who are trained, the ability can be adopted as the opportunity to be initiated in the exercise of permanent citizenship, and not only one borrowed for electoral times, because of the absence of the spouse or other reasons.

This training experience with gender perspective allowed, particularly in women, to acquire and apprehend tools and knowledge for self-recognition as people with rights that strengthen them and position them in their first steps as citizens.

- End of the English version -

in political sciences, an attorney, a psychologist as social service lender, in the three cases with scarce professional experience. In part, this could be the reason why for some women it was an unknown office and they ignored the services it offered. The current administration (2014-2016) did not renovate the permanence of this office.

\section{Literatura Citada}

Avilés, Ximena, María Fernanda Cabrera, y Patricia Gálvez. 2005. La construcción de la ciudadanía de las mujeres. In: Silva Charvet Erika (ed) Identidad y ciudadanía de las mujeres, pp. 121-167. Ecuador, Ed. Abya Yala.

Báez, Clara, y Denisse Paiewonsky. 2002. Género y ciudadanía. Recomendaciones para incorporar la perspectiva de Género al Programa FOSC. (Colección Sociedad Civil. Serie de Documentos de trabajo 16), República Dominicana, BID, OXFAM.

Bulbeck, C. 1998. Individual versus Community in Re-Orienting Western Feminisms: Women's Diversity in a Postcolonial World, Cambridge, Cambridge University Press en http://www.womenink.org

Castells, Irene. 2005. La ciudadanía revolucionaria. In: Erytheis. http://idt.uab.es/erytheis/castells_es.htm

Celarié Hidalgo, Nidia, Olga Lucio Rodríguez A., Julio Morales López, Blanca Suárez San Román, y Emma Zapata Martelo. 2008. Promotoras: cambio y desarrollo local, México, INDESOL.

Fals Borda, Orlando. 2008. El socialismo raizal y la Gran Colombia bolivariana. Investigación acción-participativa. Editorial El Perro y La Rana. Col. Alfredo Maneiro, Caracas. In: http://josejavierleon.blog.com.es/2009/08/09/investigacion-accion-participativa-6685948/ 
Flores Hernández, Aurelia. 2010. A las mujeres por la ley no nos tocan tierras. Género, tierra, trabajo y migración en Tlaxcala, México, Universidad Autónoma de Tlaxcala, Colegio de Tlaxcala A.C.

Flores Osorio, Jorge Mario, y Liza Yasmín Gómez Jasso. 1999. Introducción a la Psicología Comunitaria, México, CEDEF.

Grondona, Mariano. 2000. Historia de la democracia, Publicaciones de la UCEMA, Argentina. In: http://www.ucema. edu.ar/publicaciones/download/documentos/175.pdf

Hernández Díaz, Jorge. 2009. Ciudadanías diferenciadas, política del reconocimiento y defensa de la identidad. In: Derecho y sociedad en Oaxaca indígena. Logros alcanzados y desafíos pendientes, Estados Unidos de América, Fundación para el Debido Proceso Legal. pp: 11-22.

INEGI (Instituto Nacional de Estadística, Geografía e Informática). 2010. XII Censo General de Vivienda del estado de Tlaxcala, Aguascalientes, México.

INMUJERES (Instituto Nacional de las Mujeres). 2009. Desarrollo local con igualdad de género, México.

Jiménez Lugo, Irma. 2005. Munícipes y municipalistas. Incorporación de la perspectiva de género en la gestión municipal, México, INDESOL.

Marshall, Thomas Humphrey. 1997. Ciudadanía y clase social. In: Revista Española de Investigaciones Sociológicas (REIS), No. 79, Centro de Investigaciones Sociológicas. In: http:// www.reis.cis.es/REIS/PDF/REIS_079_13.pdf, pp. 297-344.

Martínez Corona, Beatriz, y Rufino Díaz Cervantes. 2005. Metodologías de capacitación de género con mujeres rurales en México, 1990-2003, México Colegio de Postgraduados.

Martínez, Víctor Leonel Juan. 2014. La ciudadanía prestada. Multiculturalidad, género y migración en municipios de Oaxaca. In: Ivonne Vizacarra Bordi (comp) La feminización del campo mexicano en el Siglo XXI. Localismos, transnacionalismos y protagonismos. México, Plaza y Valdés. pp: 331-356.
Masbernat, Nancy. 1999. Publicación de la discusión del Taller La ciudadanía a nivel local. Realizado el 10 de noviembre de 1999. Proyecto Estado y generación de espacios democráticos. p. 4. In: http://www.capp.uchile.cl/espdem/ciudadnivellocal.

Morgade, Graciela. 2011. Toda educación es sexual. Buenos Aires. Editorial La Crujía.

Perissé, Agustín Horacio. 2010. La ciudadanía como construcción histórico-social y sus transformaciones en la Argentina contemporánea. In: Nómadas Revista Crítica de Ciencias Sociales y Jurídicas, No. 26, España, Universidad Complutense de Madrid.

Saltor, Carlos Eduardo, y Alfredo Espindola. 2008. Sobre la idea de ciudadanía. In: Cuadernos de la Facultad de Humanidades y Ciencias Sociales, No. 34, Argentina, Universidad Nacional de Jujuy. pp: 269-277.

Sever, Charlie. 2004. Género y ciudadanía. Colección de Recursos de Apoyo. Development Research Centre on Citizenship, Participation, and Accountability Institute of Development Studies. In: http://www.ids.ac.uk/bridge.

Silva Charvet, Erika. 2005. Contexto histórico y conceptos políticos feministas. En: Identidad y ciudadanía de las mujeres, Ecuador, Editorial Abya Yala. pp: 11-54.

Vargas Valente, Virginia. 2000. Una reflexión feminista de la ciudadanía. In: Revista Estudos Feministas, No. 2, Vol. 9, Brasil, Universidad Federal de Santa Catarina. pp: 170-190.

Vélez Bautista, Graciela. 2006. Género y ciudadanía: Las mujeres en el proceso de construcción de la ciudadanía. In: Espacios Públicos, No. 17, Vol. 9, México, UAEM. pp: 376-390.

Yuval-Davis, N. 1997. Women, Citizenship and Difference. In: Feminist Review, No. 57. pp: 4-27. 